\title{
Anticancer Herbs for Improving the Quality of Life
}

\author{
Darakhshan Qaiser*1, Anurag Srivastava ${ }^{1}$, Afshan Qaiser ${ }^{2}$ \\ ${ }^{1}$ Department of Surgery, All India Institute of Medical Sciences, New Delhi (India) \\ ${ }^{2}$ Clinical Research Unit, Department of Pharmacology, Gandhi Medical College, Bhopal (India) \\ ${ }^{*}$ Corresponding author email: qaiser.d@gmail.com
}

Received: 23 February 2018 / Revised : 25 April 2018 / Accepted: 02 May 2018 / Published: 03 May 2018

\begin{abstract}
In the world, there are many systems of traditional medicine. Cancer is the major public health burden both in developing and developed countries. Around 50\% of existing medicines for cancer treatment have plants origin. Anticancer property of some plant extracts proven to be significantly effective in the treatment of cancer. Many herbs like sadabahar, turmeric, Kalonji, cannabis, garlic, flaxseed contain active components which may be effective in prevention and treatment of many cancers. The present review focuses on the evidence of health benefit of various herbs though recent human and animal studies.
\end{abstract}

Keywords: Anticancer, Herbs, Anti-angiogenic, Immunity, anti mitotic, quality of life.

\section{Introduction}

Hippocrates was the father of western medicine. He used the term "cancer" for the first time. The Greek word is "carcinoma and Karakinos" used to express cancer [1]. Cancer is the leading cause of death in the age group 45-65yrs in the developed countries. Cancer is surpassing the other fatal diseases for morbidity due to change of lifestyle, food habits and non availability of curative treatment for many diseases [2]. World Health Organisation (WHO) predicts that around 15 million new cases of cancer in 2020 [3]. Surgery, radiotherapy, and chemotherapy are the standard techniques of treatment of cancer. These standard techniques are costly, and having serious side effects affecting the quality of life like nausea, stomaties, diarrhea, and anemia thrombocytopenia of cancer patients [4]-[6]. Besides the severe side effects of chemotherapy and radiotherapy, these therapies also develop gradual resistance of cancer cells against the treatment [7].

According to WHO report, more the $80 \%$ of population in the developing countries primarily employ traditional medicine for various diseases, efficacy, their affordability, availability and safety [8]. Many plants are loaded with chemo protective agents and play important role in controlling cancer symptoms and treatment. Herbal preparation plays a vital role in treatment and prevention of cancer. Inhibition of mitosis is the basis of cancer therapy. Several studies indicate that medicinal plants have anti-cancer activity. Medicinal plants are cheaper, easily available and usually cause no toxicity as compared to the allopathic drugs [9]. From 1984 to 1994 , FDA confirmed that $60 \%$ of drugs were prepared from the natural sources specially from plant origin [10]. From 121 approved drugs for cancer treatment, 90 were derived from herbal medicine. From 1981 to 2002, 65 new drugs were registered for the treatment of cancer out of which 48 having natural products including:

- Vinca alkaloids: Vincristine, Vinbalstin, Vindesine, Vinorelbine

- Taxanes: Paclitaxel, docetaxel

- Podphyllotoxin and its derivatives: Topothecon, irinothecan

- Anthracyclines: Doxorubicin, Daunorubicin, epirubicin, idarubicin [7,11]. 
Ayurveda tried many herbal and Rasayana remedies with varying success, but their main approach is preventive [12]. These anti-cancer herbs inhibiting cancer activating enzymes and stimulate the DNA repair mechanism and also promote the anti-oxidant action, Hence, enhancing the immune cells activity. Some herbs also reduce the side effects of chemotherapy and radiotherapy. Hence, herbal preparation can be propose to kill cancer cells devoid any harm to normal cells and side effects of traditional anticancer therapies

\section{Herbal Drugs}

Herbal drugs include Plants, combination of plants, herbal complexes. Herbal plants were used all over the world in different form both in allopathic and traditional medicine [13].

\subsection{Kinds of Herbal Medicines}

Herbal medicines are divided in to two categories:
A. Immuno-modulating Herbs
B. Chemoprotective or Adapto genic herbs.

\subsubsection{Immuno-modulating Herbs}

play key important role in the treatment of cancer patients by enhancing their immunity. Since, cancer cells decrease the surveillance of immune system due to low immunogenicity in the cancer patients. Majority of herbal medicine stimulate the immunity. In addition, these medicines protect the bone marrow against myelosuppressive effects of chemotherapy [1].

\subsubsection{Chemoprotective or Adaptogenic Herbs}

Chemopreventing Herbal medicines inhibit the development of carcinogenic by inducing apoptosis [14, 15]. Curcumin induce the apoptosis in cancer cells by blocking NF-KB

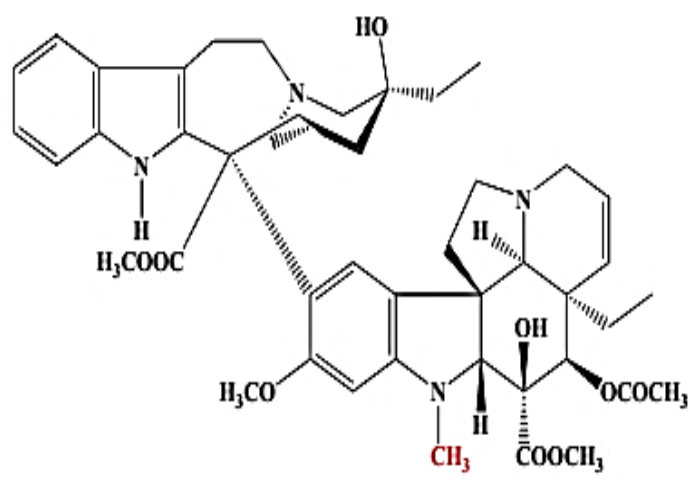

signalling pathway through controlling IKB enzyme phosphorylation [16,17]. The main aim of herbal medicines in cancer treatment is the prevention of cancer by generating unfavourable environment for the cancer cells. In addition, prevention of recurrence by enhancing the immunity of the patient body and also reducing the side effects of chemotherapy and radiotherapy $[1,3]$.

\subsection{Why People use Herbal Medicine}

Around $75-80 \%$ population in the developing countries use herbal medicine for the treatment of cancer [18]. Patients suffering from cancer are inclined to use herbal medicine due to hope to cure cancer, to prevent metastasis, enhance immunity, reduce stress, and feel relaxed [19]. We reviewed some well-known and easily available herbs which can be used prevention therapy of cancer as an adjuvant therapy.

\section{$3 \quad$ Health Benefits of Different Herbs}

\subsection{Catharanthus Roseus or Vinca Rosea (Periwinkle)}

Vinca resea (Periwinkle) was the first anti cancer herb. Periwinkle contains vinca alkaloids which contains vincristine (leurocrystine), vinblastin, alstonine, ajmalicine and reserpine [20,21]. In 1960 the alkaloids of vincristin (VCR) and vinblastin (VBT) are the first having anti cancer property [14]. These alkaloids show anticancer property by binding with tubulin (microtubule protein). Therefore, microtubules breakdowns and inhibits the formation of spindes in the metaphase hence, stop the division of cancerous cells [22, 23]. Vincristine and vinblastin both are significantly different in their structure and utility (Figure 1).

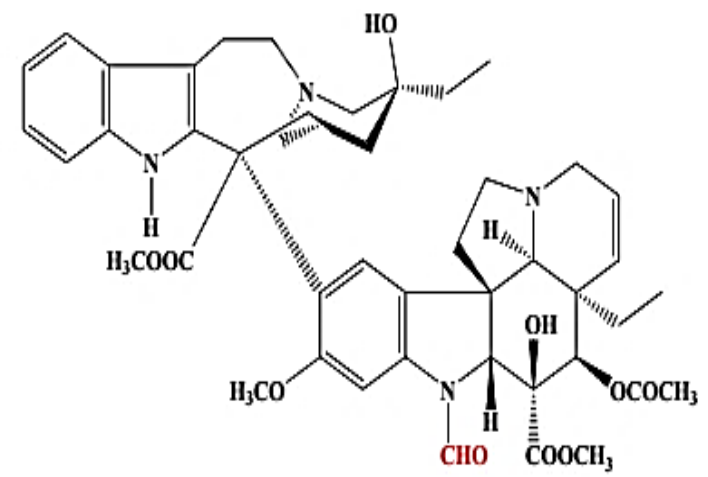

Figure 1: Molecular structure of (a) vinblastine (b) Vincristine [24] 


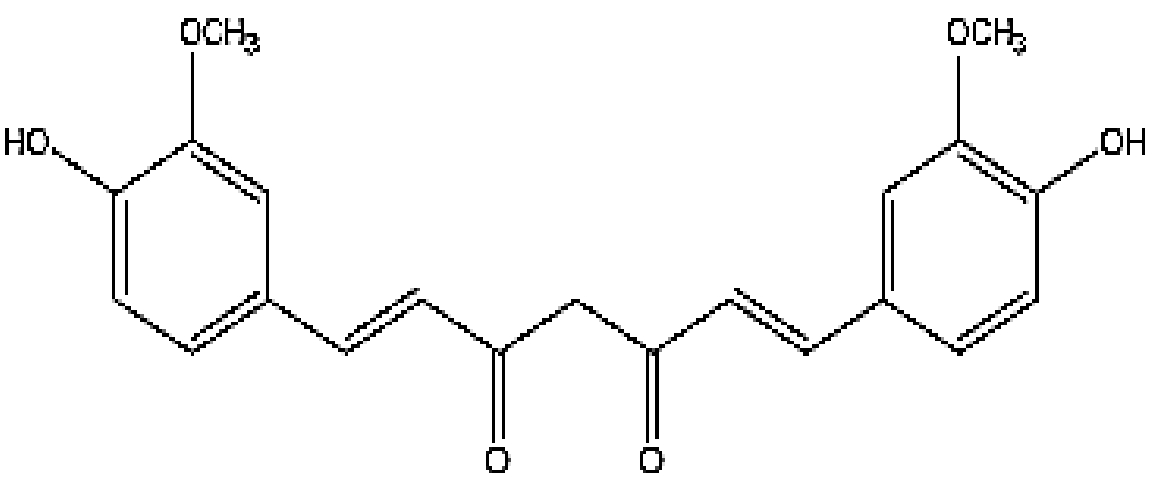

Figure 2: Molecular structure of curcumin [28]

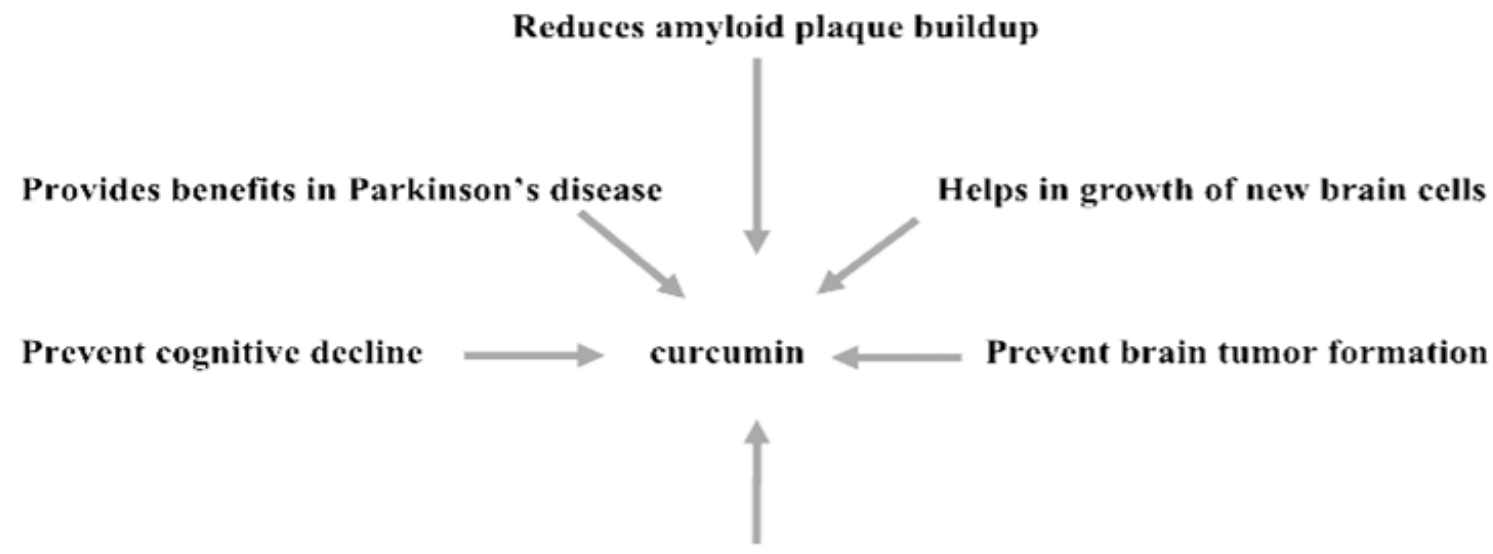

Protects brain cells from stroke damage

Figure 3: Action of curcumin [29]

Vinblastine used in the treatment of Hodgkin's disease, non Hodgkin's lymphoma and cancer of kidney. While, vincristine used with combination of other anticancer agents for treatment of lymphocytic leukaemia and cancer of breast, lung, liver, cervix [13]. Currently, herbal compounds of periwinkle have been approved by FDA to treat the neoplasm and vincristine is the commonly used drug for the treatment of breast cancer.

\subsubsection{Side Effects of Periwinkle}

Vinblastine has some side effects like bone pain, loss of appetite, misery, dizziness, constipation, hair loss and stomach pain.

\subsection{Curcuma Longa (Turmeric):}

In Indian food turmeric use as a spice to add color and flavour. Curcuma Longa (CL) shows wide spectrum of therapeutic effects. It contains curcumin, which is the highly pleiotropic molecule (Figure 2). CL is anti-oxidant, anti-inflammatory, anti-mutagenic, anti-tumour, anti-fungal, antiviral, anti-bacterial and hepatoprotective [25]. Curcumin prevents the production of harmful eicosanoid such as PGE-2 hence, inhibits the growth of cancer cells [13]. Administration of $1 \mathrm{~g} /$ day of turmeric up to 9 months exerted significant effects on the regression of precancerous lesion of palatal cancers [26]. No acute toxicity effect was observed in the administration of turmeric powder with a dose up to $10 \mathrm{~g} / \mathrm{kg}$ [27]. Curcuminoids extracted from Curcuma longa (Turmeric) such as curcumin (Diferuloyl-methane) suppress cancer cells at every step, i.e. initiation, growth and metastasis. Curcumin arrests the cancer cell proliferation in G2/S phase and induces programmed cell death (apoptosis). It inhibits angiogenesis which is a critical step in the growth and metastasis of cancer. Figure 3 shows the action mechanism of curcumin for brain tumour. 
Curcumin used to care for squamaous cell carcinoma of skin and ulcerated oral cancer. It also prevents malignant transformation of leukoplakia [14]. Curcumin and Genistein (isolated from Glycine max) act synergistically to inhibit growth \& spread of oestrogenpositive breast cancer cells.

Table 1: Active components of Nigella Sativa

\begin{tabular}{|c|c|c|}
\hline Group & Sub Group & Active Components \\
\hline Alkaloida & - & $\begin{array}{l}\text { Nigrllicine, } \\
\text { Nigellidine, } \\
\text { Nigellimine }-\mathrm{N} \text { - } \\
\text { Oxide }\end{array}$ \\
\hline Coumarins & - & $\begin{array}{l}\text { 6-methoxy- } \\
\text { coumarin, } 7 \text { hydroxy } \\
\text { coumarin, } 7 \text { oxy } \\
\text { coumarin. [33]-[35] }\end{array}$ \\
\hline \multirow[t]{2}{*}{ Saponins } & Triterpenes & Alpha Hedrin \\
\hline & Steroidal & $\begin{array}{l}\text { Steryl gluosides, } \\
\text { Ncetyl } \\
\text { Gluocoside }[36]\end{array}$ \\
\hline $\begin{array}{l}\text { Carbohydrates } \\
(33.9 \%)\end{array}$ & - & - \\
\hline \multirow[t]{2}{*}{$\begin{array}{l}\text { Fixed Oil (32- } \\
40 \%)\end{array}$} & $\begin{array}{l}\text { Saturated } \\
\text { fatty acid }\end{array}$ & $\begin{array}{l}\text { Palmitic, Stearic, } \\
\text { and myristic acid, } \\
\text { Beta-sitosterol, } \\
\text { Cycloeucalenol, } \\
\text { Cycloartenol, Sterol } \\
\text { ester, and Sterol } \\
\text { glucosides [37] }\end{array}$ \\
\hline & $\begin{array}{l}\text { Unsaturated } \\
\text { Fatty Acid }\end{array}$ & $\begin{array}{l}\text { Arachdonic, } \\
\text { eicosadienoic, } \\
\text { linoleic, linolenic } \\
\text { oleic and almitoleic } \\
\text { acid [37] }\end{array}$ \\
\hline $\begin{array}{l}\text { Protein } \quad(16- \\
19.9 \%)\end{array}$ & Amino acid & $\begin{array}{l}\text { Arginine, glutamic } \\
\text { acid, leucin, lysine, } \\
\text { proline [38] }\end{array}$ \\
\hline Fiber $(5.5 \%)$ & - & - \\
\hline $\begin{array}{l}\text { Minerals } \\
(1.79-3.74 \%)\end{array}$ & - & - \\
\hline Water $(6 \%)$ & - & - \\
\hline $\begin{array}{l}\text { Volatile Oil } \\
(0.4-0.45 \%)\end{array}$ & - & $\begin{array}{l}\text { Nigellone, } \\
\text { thymoquinone, } \\
\text { thymohydroquinone, } \\
\text { dithymoquinone, } \\
\text { thymol, carvacrol } \\
{[38,39]}\end{array}$ \\
\hline
\end{tabular}

\subsection{Nigella Sativa (Kalonji)}

Nigella Sativa uses to promote health and fight disease especially in Middle East, Southeast Asia. Nigella sativa has been used for the treatment of various diseases. In south Asia it is known as kalonji. The Arabic name of Nigella Sativa is Habat-ul-Sauda and in English it is called black cumin [30]. It is an annual herb and used as natural medicine and cultivated in different parts of India and Pakistan. Traditionally, it is used to promote general health conditions and in the cold, headache, microbial infections. It is also use as a diuretic diaphoretic, stomachic, liver tonic, and digestive. Nigella Sativa improves the immune system when administered $1 \mathrm{gm}$ twice a day reported by researcher [31] Kalonji also enhances the immune system by improving helper T Cells (T4) to suppressor T cells (T8) ratio and improving the natural killer cell activity with decrease in the immune globulin (IgA, IgG, and $\operatorname{IgM}$ ) level [32]. Thymoquinone is the active component of Nigella Sativa shown in the figure 4. The chemical composition and active principle components of Nigella Sativa is indicated in Table 1 [25].

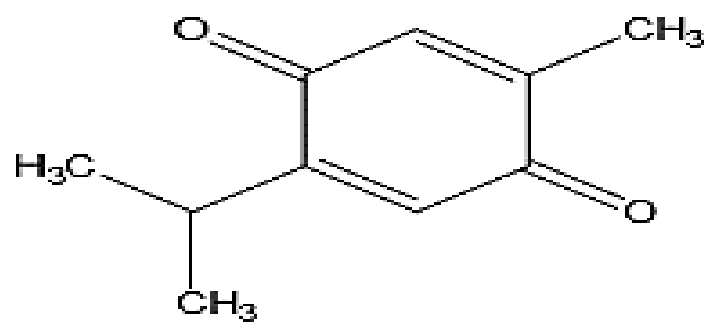

Figure 4: Structure of thymoquinone [28]

\subsection{Anti-cancer Activity of Nigella Sativa}

Nigela Sativa, has been used as a tonic to promote heath and treatment of various diseases [40]. It is immune-potentiating [39], immune-modulating, and has interferon like actions. Hailat et al; observed that the natural killer cell activity enhanced by $200-300 \%$ for advanced cancer patients receiving multimodality immune therapy in which kalonji was one of the components. They also investigated the anti-cancer activity of Nigella Sativa on cancer cell lines and in animal model. Ethanolic extract of NIgella Sativa inhibits cancer cells and progression of endothelial cells 
Qaiser et al., Int. Ann. Sci.; Vol. 5, Issue 1, pp: 1-11, 2018

in-vitro [41,42]. Alcoholic extract also used to cure oral cancer [43]. Alcoholic extract either alone or in combination with $\mathrm{H}_{2} \mathrm{O}_{2}$ was found to be effective in inactivating MCF-7 breast cancer cells in vitro [44].

Active components of Nigella Sativa, Thymoquinone and dithymoquinone have strong anticancer activity against various cancers [44], including prostate, pancreas, uterus, cancers of the colon, malignant lymphoma, malignant ascites, malignant melanoma, leukaemia and sarcomas. Thymoquinone is effective in both hormone-refractory and hormone-sensitive prostate cancer. Nigella sativa kills cancer cells by binding to the asialofeutin (lectin) on the surface of cancerous cells, causing their aggregation and clumping. Nigella sativa also possesses immuneenhancing and anti-inflammatory properties. It protects against liver cancer. Thymoquinone and dithymoquinone show cytotoxic effect on the multi drug resistant human tumour which was 10fold more resistant to doxorubicin and etoposide [45].

\subsubsection{Anti-Oxidant Property of Nigella Sativa}

Nigella Sativa also shows anti-oxidant property. Thymoquinone shows protective effects on haematological, hepatic conditions induced by anti-cancer drugs. Thymoquinone and fixed oil of Nigella Sativa also inhibit non-enzymetic peroxidation in oxbrain phospholipid liposomes. Hepatoprotective effect of Nigella Oil and thymoquinone is found to be due to anti-oxidant property [46,47]. Nigella Sativa with crystein, vitamin $\mathrm{E}$ and crocus sativa protect cisplatin induced haematological hepatic and renal toxicities [48]. Butits et al reported that the Essential oil of Nigella Sativa and its four constituents (thymoquinone, Carvacrol, t-anethol and 4-terpineol) exhibit anti-oxidant effect on various chemical assays like diphenylpicrylhydracryl assay, and assay for nonenzymetics lipid peroxidation in liposomes and deoxyribose degradation assay $[30,40]$.

\subsubsection{Toxicity Effect of Nigella Sativa}

There is acute toxic effect of Nigella Sativa when administered orally $25 \mathrm{~g} / \mathrm{Kg}$. However, toxic symptom appears when $25 \mathrm{~g} / \mathrm{kg}$ is administered intravenously [22]. Nigella Sativa has significant effects on biological systems. It's Ethanolic and aqueous extract as well as its volatile oil possess beneficial effects.

\subsection{Cannabis Sativa (Cannabis):}

Cannabis is the versatile material used to relief from pain, depression, nausea caused by chemotherapy in the treatment of cancer. It also works as the appetite suppressant. $\Delta^{9}$ tetrahydrocannabinol (THC) is the main constituent found in the cannabis (molecular structure is shown in figure 5) which is responsible for the pharmacological activity of cannabis in the medical field [49].

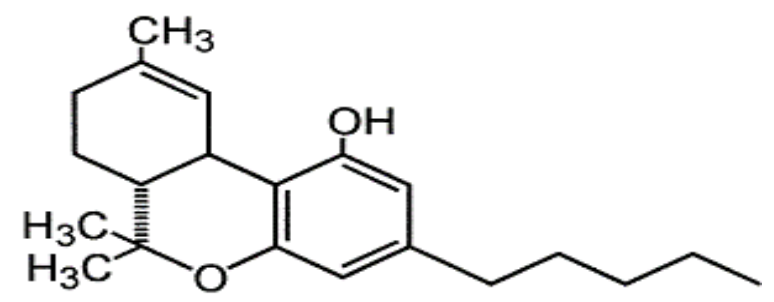

Figure 5: Molecular structure of Tetrahydrocannabinol (THC) [28]

THC produced unique psychosomatic effects in human, including sedation, euphoria, altered sensory input and impaired cognitive functions. It also effects on the vital organs like heart (tachycardia), lungs (alveolar dilation) [50]. THC has an anti-emetic effect on animal [51] and in human [52, 53]. In 1990, Plasse et. al; [54] demonstrate the positive effects of THC in appetite increase in HIV positive and cancer patients. Cannabinoids have two receptors CB1, andCB2 [55]. CB1 receptor found in brain, periphery tissue, sensory nerve fiber, testis and immune system [56]. The highest level of CB1 receptor found in brain which is responsible for the neuropsychological functions altered by the cannabinoids [57]. CB2 receptor is mainly present in the immune tissue i.e; spleen, mast cells, peripherial blood leukocytes, thymus, pancreas, bone marrow, macrophages/ monocytes tonsils [56]. CB1and CB2 receptors are activated by THC [58]. Cachexia is the most common complication in the cancer patients which arises due to the metabolic changes created by tumours and cytoknines and other 
endogenous substances [58]. Studies indicate that increase of appetite and weight gain with the intake of marijuana (cannabis) for cancer patients and AIDS related anorexia [59,60].

Nausea and vomiting are associated with the cytotoxic drug effects (during chemotherapy) and radiation. The nausea and vomiting also suppress the appetite. Nabilone (Cesamet) a synthetic derivative of THC is found to be effective in controlling chemotherapy induced nausea and vomiting [61]. Cannabinoids is also effective in treating nausea and vomiting for the children undergoing chemotherapy $[62,63]$.

\subsubsection{Toxicity Effect of Cannabis}

Side effects of cannabis are not often seen in the physical aspects, rather in mental or cognitive domain such as inability to recognised distant objects and time interval and memory processes.

\subsection{Allium Sativum (Garlic)}

Initially Allium Sativam used in Egypt, Greece, Europe, India, China, Rome and Russia. Garlic has preventive potentials and has enhancing effects on immune system [28]. Hippocrates was the first who recommend the use of Allium Sativum for the treatment of cancer. More than 100 biological metabolites are available in Allium Sativum, which includes Alliin, Allinase, Allicin, $S$ allylcrystine (SAC), di-allyl-di-sulphide (DADS), Diallyl-tri-sulphide cristine (DATS) and Methyl-allyl-trisulphide (molecular structure is shown in figure 6) [64]. In Allium Sativum bioflavonoids: quercetin and cyaniding are responsible for the anti-oxidant property. DADS, SAC and DATS cristine have anti-cancer property. Garlic shows significant role in the treatment of intestine cancer. The anticancer effects of garlic are due to its metabolic by products of organo-sulphur components $[65,66]$. These by products are DADS, SAC and DATS cristine and allicin [51]. When MCF-7 (ER+) and MDA-MB231 (ER-ve) treated with S-allyl mercaptocystein, cancer cell growth was inhibited via inducing cell cycle arrest in G0 /G1 phase [67]. Cell cycle redistribution is the important role in human gastic cancer cells when treated Diallyl disulfied modulate anticarcigogenic effect [68]. A study of epidermiology indicates that the garlic reduces the risk of gastric cancer $[69,70]$.

Aged garlic produces from the fresh garlic for more than 10 months. The extract of aged garlic decrease the aberrant crypt foci (ACF) in colorectal cancer [71]. Extract from the aged garlic shield the DNA from the damaging effect of carcinogen, enhance the activity of detoxyfing enzymes, and increase the immunity of the body. Study from Dene National Medical centre and Hospital from Japan reveals that the extract of aged garlic can reduce the side effects of radiotherapy and chemotherapy $[24,25]$. The compound extracted from the garlic extract is also useful in the treatment of other cancers. A compound extracted from the garlic, Z-ajoene is useful in the treatment of gioblastoma [25, 72]. Another sulphur compound of garlic extract Thiacremonone, inhibits the lung cancer cell growth via inhibiting the Gpx activity of peroxiredoxin 6 through interaction [73].

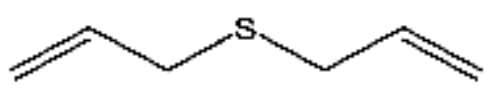

(a)

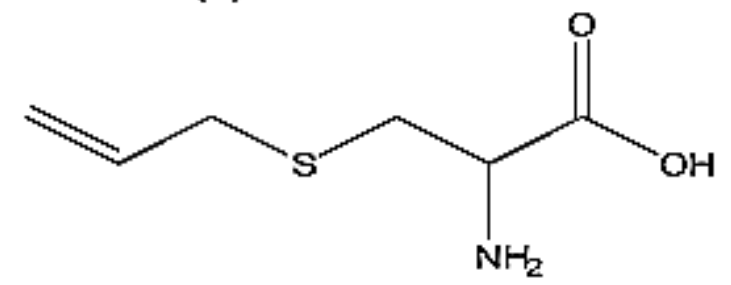

(d)

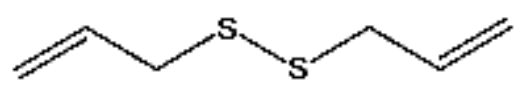

(b)

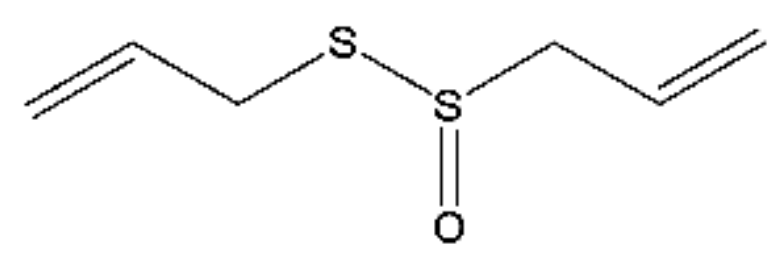

(e)

Figure 6: Molecular Structure of-

(a) diallyl sulphide, (b) diallyl disulfide, (c) diallyl trisulfide, (d) S-allyl mercaptocysteine, (e) allicin 
Qaiser et al., Int. Ann. Sci.; Vol. 5, Issue 1, pp: 1-11, 2018

The mechanism showing the antitumor activity, stimulating the lymphocytes and macrophages used to kill cancer cells and interfaces with tumour cells metabolism is shown in figure 7 .

Alliin (odorless)

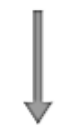

Allicin (garlic odor)

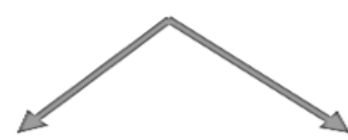

Diallyl disulphide

Diallylsulphides

Diallyl trisulphide

Ajoenes

Figure 7: Mechanism of garlic showing antitumor activity

\subsection{Zingiber Officinale (Ginger)}

Studies suggest that the ginger and its bioactive constituents such as gingerol, paradols and shogals [74] and they are useful in cancer prevention and treatment [89]. Gingerols isolated from Zingiber officinale inhibits growth \& spread of various cancers including that of the ovary, cervix, colon, rectum, liver, urinary bladder, oral cavity, neuroblastoma and leukaemia by inducing apoptosis [24]. Gingerols are the series of phenolic compounds which are different in length in their unbranched alkyl side chain reposted by [76]. Figure 8, depicts the chemical structure of active constituents of gingerols. The most active individual component, 6-shogaol, isolated from Zingiber officinale, inhibits growth \& spread of many cancers particularly the ovarian cancer by blocking formation of new blood vessels and by inducing apoptosis \& autophagy. 6-gingerol also inhibits adhesion, invasion and mobility of MDA-MB231 breast cancer cells [28] and also suppresses the proliferation of breast cancer cells by inducing apoptosis. It is also effective even in chemotherapy resistant ovarian cancer. Zingiber officinale also possesses antioxidant, antimutagenic and anti-inflammatory properties and reduces side effects of chemotherapy \& radiotherapy.

\subsection{Flaxseeds}

Flaxseeds are the small golden brown coated seeds. They are also known as linseed. Their latin name is Linum usitatissimum which means very useful. They have potential health benefits like reduction of cardiovascular disease, diabeties, cancer, arthritis, osteoporosis and neurological disorders [77]. Flaxseeds contains all active ingredients like dietary fiber, omega-3 fatty acid, $\alpha$ - linolenic acid (ALA), short chain of polyunsaturated fatty acids (PUFA), lignin proteins and array of antioxidant [78]-[80]. Flaxseeds have estrogenic activity due to metabolism of lignon to enterodiol, enterolactone. This metabolism occurs in the digestive tract. Flaxseeds have dominant anticancer activity [81, 82]. Observational data of Gallian et al [98] demonstrate that flaxseeds are protective against breast cancer with the intak of $1 / 4$ cup (approximately 32 grams ground flaxseeds) [83]. It also inhibits the colon, skin, and lung cancer. Several studies demonstrate that flaxseeds and its active components shows antiangiogenic [84] and increase apoptosis [85] effect hence, reducing the tumour size $[101,102]$. Nutritional and chemical composition of flaxseeds is available in Table 2.

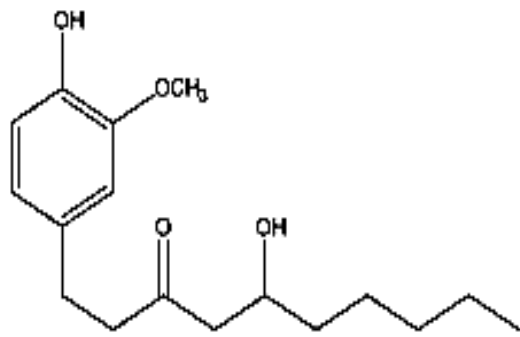

(a)

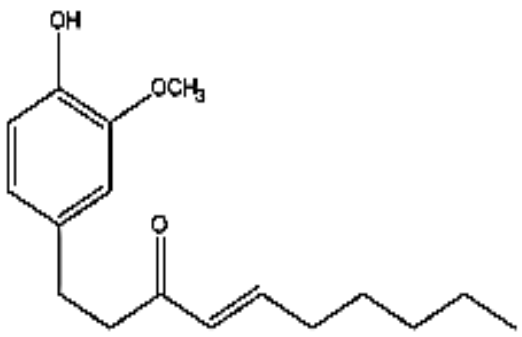

(b)

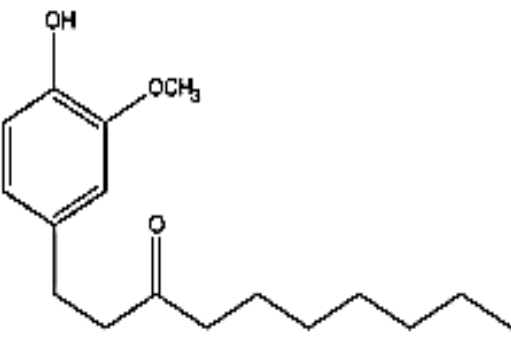

(c)

Figure 8: (a) Structure of 6-gingerol, (b) 6-Shogaol, (c) Paradol 
Table 1: Nutritional and chemical composition of Flaxseeds [77]

\begin{tabular}{|l|l|l|l|}
\hline Nutrients & $\begin{array}{l}\text { Quantity/ } \\
\text { 100g of } \\
\text { seed }\end{array}$ & Nutrients & $\begin{array}{l}\text { Quanti } \\
\text { ty/ } \\
\text { 100g of } \\
\text { seed }\end{array}$ \\
\hline Carbohydrates & $29.0 \mathrm{~g}$ & Potassium & $831 \mathrm{mg}$ \\
\hline Total fats & $41.0 \mathrm{~g}$ & Phosphorous & $622 \mathrm{mg}$ \\
\hline Protein & $20.0 \mathrm{~g}$ & Calcium & $236 \mathrm{mg}$ \\
\hline Linolenic acid & $23.0 \mathrm{~g}$ & Magnesium & $431 \mathrm{mg}$ \\
\hline Lignans & $\begin{array}{l}10- \\
2,600 \mathrm{mg}\end{array}$ & & \\
\hline Folic Acid & $112 \mathrm{mg}$ & & \\
\hline
\end{tabular}

\section{Conclusion}

Cancer is the major public health burden. Many herbs and plant products have been demonstrated to have anti-tumour activity. Large population-based studies are required to study the preventive role of these (Kalonji, turmeric, Garlic, Cannabis, Flaxseed) herbs. Several herbs have anticancer effects on skin, breast, lung, prostate cancer (Shows in table 3). Some of the herbs may also be useful in increasing the therapeutic effect of radiotherapy and chemotherapy.

\section{Acknowledgment}

One of the authors, Darakhshan Qaiser, would like to thank the University Grant Commission, India for providing financial support as postdoctoral fellowship for women.

\section{Conflict of Interest}

The authors declare that they have no conflict of interest.

\section{How to Cite this Article:}

D. Qaiser, A. Srivastava, and A. Qaiser, "Anticancer Herbs for Improving the Quality of Life", International Annals of Science, vol. 5, no. 1, pp. 1-11, May 2018. doi: 10.21467/ias.5.1.1-11
Table 3: Herbs and their anti- cancer effects

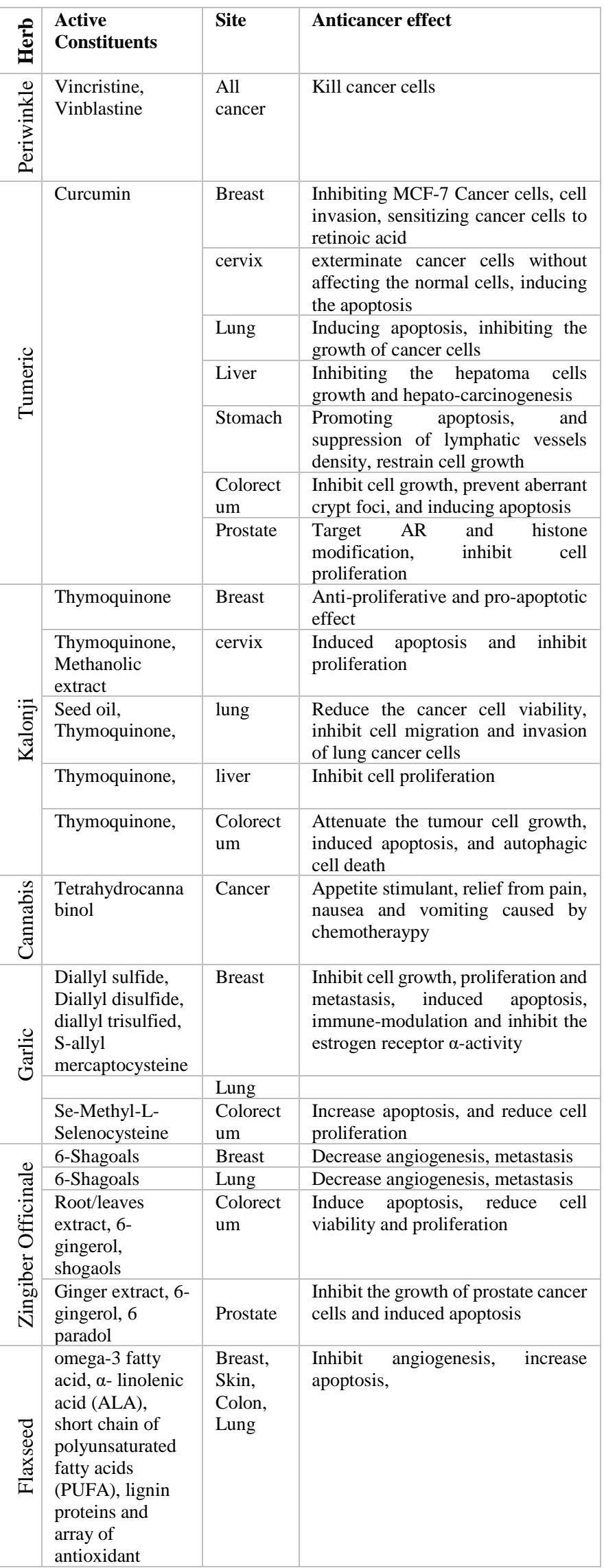


Qaiser et al., Int. Ann. Sci.; Vol. 5, Issue 1, pp: 1-11, 2018

\section{References}

[1] E. Safarzadeh, S. S. Shotorbani, B. Baradaran, "Herbal Medicine as Inducers of Apoptosis in Cancer Treatment", Adv Pharm Bull, vol. 4(Suppl 1), pp. 421427, August 2014.

[2] P.N. Notani, "Global variation in cancer incidence and mortality” curr.sci, vol. 81, NO. 5, pp. 465-474, SEPTEMBER 2001.

[3] J. Tavakoli, S. Miar, M.M. Zadehzare, H. Akbari, "Evaluation of Effectiveness of Herbal Medication in Cancer Care: A Review Study", Iran J Cancer Prevent vol. 5 no. 3, pp. 144-156, 2012

[4] M.R. Adhvaryu. N. Reddy, M.H. Parabia, "Anti-Tumor Activity of Four Ayurvedic Herbs In Dalton Lymphoma Ascites Bearing Mice and Their Short-term in vitro Cytotoxicity on Dla- Cell-Line", Afr. J. Trad. CAM, vol. 5, no. 4, pp. 409-418, 2008.

[5] F.Qi, A. Li, Y. Inagaki, J. Gao, J. Li, N. Kokudo, X. K. $\mathrm{Li}, \mathrm{W}$. Tang, "Chinese herbal medicines as adjuvant treatment during chemo- or radio-therapy for cancer", Biosci Trends, vol. 4 no. 6, pp, 297-307, 2010.

[6] G. Yang, X. Li, X. Li X, L. Wang, J. Li, X. Song, J.Chen, Y.Guo, X. Sun, S. Wang, Z. Zhang, X. Zhou, J. Liu, "Traditional chinese medicine in cancer care: a review of case series published in the chinese literature", Evid Based Complement Alternat Med vol. 2012 no. 751046, pp. 1-8, 2012.

[7] Z. Wang, N. Wang, J. Chen, J. Shen, "Emerging glycolysis targeting and drug discovery from chinese medicine in cancer therapy", Evid Based Complement Alternat Med, vol. 2012, no. 873175, pp. 1-13, 2012.

[8] S.C. Kaul, Y. Ishida, K. Tamura, T. Wada, T. Iitsuka, S. Garg, M. Kim, R. Gao, S. Nakai, Y. Okamoto, K. Terao, R. Wadhwa, "Novel Methods to generate active ingredients enriched Ashwagandha leaves and extract", Plos one, vol. PLOS ONE, vol.11, no. 12, e.0166945, 2016.

[9] N. Agarwal , C. Majee, G. S. Chakraborthy, "Natural Herbs as Anticancer Drugs", Int.J. Pharma \& Ind. Res., vol.4, no.3, pp 1142-1153, 2012.

[10] D.R.N. Kumar, V.C. George, P.K. Suresh, R.A. Kumar, "Cytotoxicity, apoptosis induction and anti-metastatic potential of Oroxylum indicum in human breast cancer cells", Asian Pac J Cancer Prev, vol. 13, no. 6, pp. 27292734, 2012.

[11] A.K. Mukherjee, S. Basu, N. Sarkar, A.C. Ghosh, "Advances in cancer therapy with plant based natural products", Curr Med Chem, vol. 8 no. 12, pp. 14671486, 2001.

[12] P. Balachandran, R. Govindrajan, "Cancer- an Ayurvedic perspective", Pharmacol. Res., vol. 51, pp. 19-30, 2005.

[13] C.S. Hall, H.O. Larsen, M. Pouliot, "People, plants and health: a conceptual framework for assessing changes in medicinal plant consumption", $J$ Ethnobiol Ethnomed vol. 8, no. 43, pp. 1-11, 2012.

[14] S.K. Pal, Y. Shukla, "Herbal medicine: current status and the future", Asian Pac J Cancer Prev, vol. 4, no. 4, pp. 281-288, 2003.

[15] S. Yang, Q. Zhao, H. Xiang, M. Liu, Q. Zhang, W. Xue, B. Song, S. Yang, "Antiproliferative activity and apoptosis inducing mechanism of constituents from Toona sinensis on human cancer cells", Cancer Cell Int, vol. 13, no. 1, pp. 12, 2013.

[16] S.M. Plummer, K.A. Holloway, M.M. Manson, R.J. Munks, A. Kaptein, S. Farrow, L. Howells, "Inhibition of cyclooxygenase 2 expression in colon cells by the chemopreventive agent curcumin involves inhibition of NF-kappaB activation via the NIK/IKK signalling complex", Oncogene, vol. 18, no. 44, pp. 6013-20, 1999.

[17] C.R. Ireson, D.J. Jones, S. Orr, M.W. Coughtrie, D.J. Boocock, M.L. Williams, P.B. Farmer, W.P. Steward, A.J. Gescher, "Metabolism of the cancer chemopreventive agent curcumin in human and rat intestine", Cancer Epidemiol Biomarkers Prev, vol. 11, no. 1, pp. 105-111, 2002.

[18] R.F. De Araujo Junior, T.P. De Souza, J.G. Pires, L.A. Soares, A.A. De Araujo,P.R. Petrovick, H.D.O. Macedo, A.L.C.de Sa' Leitao Oliveira, G. C.B. Guerra, "A dry extract of Phyllanthus niruri protects normal cells and induces apoptosis in human liver carcinoma cells", Exp Biol Med, vol. 237, pp. 1281-1288, 2012.

[19] C. Gratus, S. Wilson, S.M. Greenfield, S.L. Damery, S.A. Warmington, R. Grieve, N.M. Steven, P. Routledge, "The use of herbal medicines by people with cancer in the UK: a systematic review of the literature", BMC Complementary and Alternative Medicine vol. 9, no. 14, pp. 9-14, 2009.

[20] G.M. Cragg, D.J. Newman, "Plants as a source of anticancer agents", J. Ethnopharmacol,vol. 100, no. 1, pp. 72-79, 2005.

[21] M.A. Jordan, "Mechanism of action of antitumor drugs that interact with microtubules and tubulin", Curr Med Chem Anticancer Agents, vol. 2, no. 1, pp. 1-17, 2002.

[22] A. Duflos, A. Kruczynski, J. M. Barret, "Novel aspects of Natural and Modified Vinca Alkaloids", Curr Med Chem Anticancer Agents, vol. 2, no.1, pp. 55-70, 2002.

[23] M.N. Islam, M.N. Iskander, "Microtubulin Binding sites as Target for developing anticancer agents", Mini Rev Med Chem, vol. 4, no. 10, pp. 1077-1104, 2004.

[24] P. Keglevich, L. Hazai, G. Kalaus, C. Szántay, "Modifications on the Basic Skeletons of Vinblastine and Vincristine", Molecules, vol. 17, pp. 5893-5914, 2012.

[25] K. Kohli, J. Ali, M.J. Ansari, Z. Rehman, "Curcumin: A natural anti-inflametory agent", Indian J. Pharmacol., vol. 37, no. 3, pp. 141-147, 2005.

[26] K. Krishnaswamy, "Indian functional foods: Role in prevention of cancer", Nutr Rev, vol. 54, no. 11 Pt 2, pp. S127-131, 1996.

[27] N. Sittisomwong, V. Leelsangluk, S. Chivapat, A. Wangmad , P. Ragsaman, C. Chuntarachaya, "Acute and subchronic toxicity of turmeric", Bull Dept Med Sci., vol. 32, no. 8, pp. 101-111, 1990.

[28] J. Zheng, Y. Zhou, Y. Li, D.P. Xu, S.Li, H.B. Li, "Spices for prevention and treatment of Cancers", Nutrients, vol. 8, pp. 495-515, 2016.

[29] Editorial, King Saud University, "Natural cures for breast cancer treatment", Saudi pharmaceutical journal, vol. 24, pp. 233-240, 2016.

[30] M.A. Randhawa, M.S. Al-Ghandi, "A review of the Pharmaco-therapeutic effects of Nigella sativa", Pakistan J. Med. Res., vol.41, no. 2, pp. 77-83, 2002.

[31] M.A. Randhawa, M.S. Al-Ghandi, "Anti-Cancer activity of Nigella Sativa (Black Seed) -A review", American J. Chinese Medic, vol. 39, no. 6, pp. 1075-1091, 2011.

[32] A. Haq, M. Abdullatif, P.I. Lobo, K.S. Khabar, K.V. Sheth, S.T. Al-Sedairy, "Nigella Sativa: Effect on human lymphocytes and polymorphonuclear leucocyte phagocytic activity", Immunopharmacology, vol. 30, no. 2, pp.147-150, 1995. 
[33] Ata-ur-Rehman, S. Malik, K. Zaman, "Nigellimine: A New Isoquinoline Alkaloid from the Seeds of Nigella sativa”, J. Nat. Prod., Vol. 55, no. 5, pp.676-678, 1992.

[34] Ata-ur-Rehman, S. Malik, H. Cun-Hung, J. Clardy, "Isolation and structure determination of nigellicine, a noval alkaloid from seeds of Nigella Sativa" Tetrahedron Lett, vol. 26, no. 23, pp. 2759-2762, 1985.

[35] A.H. Rizvi, M.M. A.Ali Khan, G. Saxena, A.A. Naqvi, "A comparative study on the chemical composition of oil obtained from whole seeds and crushed seeds of Nigella sativa L. from India", J. Biol. Chem. Research., vol29, no. 1, pp. 44-51, 2012.

[36] S.S. Kumara, B.T. Huat, "Extraction isolation and characterization of anti-tumour principle, alpha-hedrin, from the seeds of Nigella Sativa", Planta Med. vol. 67, no. 1, pp. 29-32, 2001.

[37] A.M. Gad, M. El-Dakhakhany, M.M. Hassan, "Studies on the chemical constitution of Egyption Nigella Sativa L. oil", Planta Med., vol. 11, no. 2, pp. 134-138, 1963.

[38] H.M. El-Fatatry, "Isolation and structure assignment of an anti-microbial principle from the volatile oil of Nigella Sativa L. seeds", Pharmazie, vol. 30, no. 2, pp. 109-111, 1975.

[39] A. Gilani, Q. Jabeen, M.A. Khan, "A review of Medical uses and pharmacological activities Nigella Sativa". Pakistan J. of Bio. Scien., vol. 7, no. 4, pp. 441-451, 2004.

[40] N. Hailat, Z. Bataineh, S. Lafi, E. Raweily, M. Aqel, M. Al-Katib, S. Hanash, "Effect of Nigella sativa Volatile Oil on Jurkat $\mathrm{T}$ Cell Leukemia Polypeptides", International Journal of Pharmacognosy, vol.33, no. 1, pp. 16-20, 2008.

[41] S.M.K. Swamy, B.K.H. Tan, "Cytotoxic and immunopotentiating effect of Ethanolic extract of Nigella Sativa seeds", J. Ethnopharmacol, vol. 70, no.1, pp. 1-7, 2000.

[42] M.J. Salomi, K.R. Panikkar, "Anti-cancer activity of Nigella Sativa”, Ancient Science of Life, vol. 8, no. 3\&4, pp. 262-266, 1989.

[43] I.O. Farah, R.A. Begum, "Effect of Nigella sativa (N. sativa L.) and oxidative stress on the survival pattern of MCF-7 breast cancer cells", Biomed Sci Instrum. vol. 39, pp. 359-364, 2003.

[44] D.R. Worthen, O.A. Ghosheh, P.A. Crooks, "The in vitro anti-tumor activity of some crude and purified components of blackseed, Nigella sativa L.", Anticancer Res. Vol. 18, no. 3A, pp. 1527-1532, 1998.

[45] P.J. Houghton,, R. Zarka, B. delas Heras, J.R.. Hoult, "Fixed oil of Nigella sativa and derived thymoquinone inhibit eicosanoid generation in leukocytes and membrane lipid peroxidation, Planta Med., vol. 61, no. 1, pp. 33-36, 1995.

[46] M.N. Nagi, K. Alam, O.A. Badary, O.A. al-Shabanah, H.A. al-Sawaf, A.M. al-Bekairi, "Thymoquinone protects against carbon tetrachloride hepatotoxicity in mice via an antioxidant mechanism" Biochem Mol Biol Int., vol. 47, no. 1, pp. 153-159, 1999.

[47] M.A. Mansour, "Protective effects of thymoquinone and desferrioxamine against hepatotoxicity of carbon tetrachloride in mice" Life Sci. , vol. 66, no. 26, pp. 25832591, 2000.

[48] M. Burits, F. Bucar, "Antioxidant activity of Nigella Sativa essential oil, Phytother Res., vol. 14, no. 5, pp. 323-328, 2000.
[49] Y. Gaoni, R. Mechoulam, "Isolation, Structure, and Partial Synthesis of an Active Constituent of Hashish", J. Am. Chem. Soc., vol. 86, no. 8, pp. 1646-1647, 1964.

[50] [50] L.E. Hollister, "Health aspects of cannabis", Pharmacol Rev., vol. 38, no. 1, pp. 1-20, 1986.

[51] H.L. Borison, L.E. McCarthy, S.W. London, "Cannabinoids and emesis", N Engl J Med. , vol. 298, no. 26, pp. 1480-1481, 1978.

[52] S.E. Sallan, N.E. Zinberg E. Frei 3rd, "Antiemetic effect of delta-9-tetrahydrocannabinol in patients receiving cancer chemotherapy", N Engl J Med., vol. 293, no. 16, pp. 795-797, 1975.

[53] S.E. Sallan, C. Cronin, M. Zelen, N.E. Zinberg, "Antiemetics in patients receiving chemotherapy for cancer: a randomized comparison of delta-9tetrahydrocannabinol and prochlorperazine", $N$ Engl $J$ Med., vol. 302, no. 3, pp. 135-138, 1980.

[54] T.F.Plasse, R.W. Gorter, S.H. Krasnow, M. Lane, K.V. Shepard, R.G. Wadleigh, "Recent clinical experience with dronabinol", Pharmacol Biochem Behav., vol. 40, no. 3, pp. 695-700, 1991.

[55] S. Munro, K.L. Thomas, M. Abu-Shaar, "Molecular characterization of a peripheral receptor for cannabinoids", Nature, vol. 365, no. 6441, pp. 61-65, 1993.

[56] A.C. Howlett, F.Barth, T.I., Bonner, G. Cabral, P. Casellas, W.A. Devane, C.C. Felder, M. Herkenham, K. Mackie, B.R. Martin, R. Mechoulam, R.G. Pertwee,, "International Union of Pharmacology. XXVII. Classification of cannabinoid receptors", Pharmacol Rev.vol. 54, no. 2, pp. 161-202, 2002.

[57] M. Herkenham, A.B. Lynn, M.R. Johnson, L.S. Melvin, B.R. de Costa, K.C. Rice, "Characterization and localization of cannabinoid receptors in rat brain: a quantitative in vitro autoradiographic study", $J$ Neurosci., vol. 11, no. 2, pp. 563-583, 1991.

[58] B.R. Martin, J.L. Wiley, "Mechanism of Action of Cannabinoids: How It May Lead to Treatment of Cachexia, Emesis, and Pain", J Support Oncol., vol. 2, no. 4 , pp. 305-314, 2004.

[59] C.L. Hart CL, A.S. Ward, M . Haney, S.D. Comer, R.W. Foltin, M.W. Fischman, "Comparison of smoked marijuana and oral Delta(9)-tetrahydrocannabinol in humans", Psychopharmacology (Berl)., vol. 164, no. 4, pp. 407-415, 2002.

[60] J. Beal, N. Flynn, "AIDS-associated anorexia", $J$ Physicians Assoc AIDS Care, vol. 2, no. 1, pp. 19-22, 1995.

[61] S. Ahmedzai, D.L. Carlyle, I.T. Calder, F. Moran, "Antiemetic efficacy and toxicity of nabilone, a synthetic cannabinoid, in lung cancer chemotherapy", Br J Cancer, vol. 48 , no. 5 , pp. $657-663$.

[62] A. Abrahamov, A. Abrahamov, R. Mechoulam, "An efficient new cannabinoid antiemetic in pediatric oncology"' Life Sci, vol. 56, no. 23-24, 1995.

[63] H.S.Chan, J.A. Correia, S.M., MacLeod, "Nabilone versus prochlorperazine for control of cancer chemotherapy-induced emesis in children: a doubleblind, crossover trial", Pediatrics, vol. 79, no. 6, pp. 946952, 1987.

[64] B. Czepukojc, A.K. Baltes, C. Cerella, M. Kelkel, U.M. Viswanathan, F. Salm, T. Burkholz, C. Schneider, M. Dicato, M. Montenarh, C. Jacob, M. Diederich, "Synthetic polysulfane derivatives induce cell cycle arrest and apoptotic cell death in human 
Qaiser et al., Int. Ann. Sci.; Vol. 5, Issue 1, pp: 1-11, 2018

hematopoietic cancer cells", Food Chem. Toxicol.vol 64, pp. 249-257, 2014

[65] M. Chiavarini, L. Minelli, R. Fabiani, "Garlic consumption and colorectal cancer risk in man: A systematic review and meta-analysis", Public Health Nutr., vol. 19, no. 2, pp. 308-317, 2016.

[66] H.L. Nicastro, S.A. Ross, J.A. Milner, "Garlic and onions: Their cancer prevention properties", Cancer Prev. Res., vol. 8, no. 3, pp. 181-189, 2015.

[67] H. Zhang, K. Wang, G. Lin, Z. Zhao, "Antitumor mechanisms of S-allyl mercaptocysteine for breast cancer therapy", BMC Complement. Altern. Med., vol. 14, pp. 270-282, 2014.

[68] H. Ling, L.F. Lu, J. He, G.H. Xiao, H. Jiang, Q. Su, "Diallyl disulfide selectively causes checkpoint kinase1mediated G2/M arrest in human MGC803 gastric cancer cell line", Oncol. Rep. vol. 32, no. 5, pp. 22742282, 2014

[69] R.T. Kodali, G.D. Eslick, "Meta-analysis: Does garlic intake reduce risk of gastric cancer?", Nutr. Cancer, vol. 67, no. 1, pp. 1-11, 2015.

[70] F. Turati, C. Pelucchi, V. Guercio, C. La Vecchia, C. Galeone, "Allium vegetable intake and gastric cancer: A case-control study and meta-analysis", Mol. Nutr. Food Res., vol. 59, no. 1, pp. 171-179, 2015.

[71] H. Jikihara, G. Qi, K. Nozoe, M. Hirokawa, H. Sato, Y. Sugihara, F. Shimamoto, "Aged garlic extract inhibits 1,2-dimethylhydrazine-induced colon tumor development by suppressing cell proliferation", Oncol. Rep., vol. 33, no. 3, pp. 1131-1140, 2015.

[72] Y. Jung, H. Park, H.Y. Zhao, R. Jeon, J.H. Ryu, W.Y. Kim, "Systemic approaches identify a garlic-derived chemical, Z-ajoene, as a glioblastoma multiforme cancer stem cell-specific targeting agent”, Mol. Cells, vol. 37, no. 7, pp. 547-553, 2014.

[73] M. Jo, H.M. Yun, K.R. Park, M.H. Park, D.H. Lee, S.H. Cho, H.S. Yoo, Y.M. Lee, H.S. Jeong, Y. Kim, J.K. Jung, M.K. Lee, N.D. Kim, S.B. Han, J.T. Hong, "Anti-cancer effect of thiacremonone through down regulation of peroxiredoxin 6", PLOS ONE, vol. 9, no. 3, pp. E91508, 2014.

[74] P. Karna, S.Chagani, S.R. Gundala, P. Rida, G. Asif, V. Sharma, M.V. Gupta, R. Aneja, "Benefits of whole ginger extract in prostate cancer", Br. J. Nutr, vol. 107, no. 4 , pp. 473-483, 2012

[75] C.Z. Wang, L.W. Qi, C.S. Yuan, "cancer chemoprevention effects of ginger and its active constituents; potential for new drug discovery", Am. J. Med. vol. 43, no. 7, pp. 1351-1363, 2015.

[76] M. M. Bernard, J.R. McConnery, D.W. Hoskin, “[10] Gingerol, a major phenolic consitituent of ginger root, induces cell cycle arrest and apoptosis in triple negative breast cancer cells", Expe.Mol.Pathol. vol.102, no. 2, pp. 370-376, 2017.

[77] A. Goyal, V. Sharma, N. Upadhyay, S. Gill, M. Sihag, "Flax and flaxseed oil: an ancient medicine \& modern functional food", J Food Sci Technol, vol. 51, no. 9, pp. 1633-1653, 2014.

[78] S. Ivanova, T. Rashevskaya, M. Makhonina, "Flaxseed additive application in dairy products production", Procedia Food Sci, vol. 1, pp. 275-280, 2011.

[79] B.D. Oomah, "Flaxseed as a functional food source", $J$ Sci Food Agric, vol. 81, no. 9, pp. 889-894, 2001.

[80] K.K. Singh, D. Mridula, J. Rehal, P. Barnwal, "Flaxseeda potential source of food, feed and fiber", Crit Rev Food Sci Nutr, vol. 51, no. 3, pp. 210-222, 2011
[81] J. Chen, P.M. Stavro, L.U. Thompson, "Dietary flaxseed inhibits human breast cancer growth and metastasis and downregulates expression of insulin-like growth factor and epidermal growth factor receptor", Nutr. Cancer, vol. 43, no. 2, pp. 187-192, 2002.

[82] W.Y. Chen, G.A. Colditz, B. Rosner, S.E. Hankinson, D.J. Hunter, J.E. Manson, M.J. Stampfer, W.C. Willett, F.E. Speizer, "Use of postmenopausal hormones, alcohol, and risk for invasive breast cancer", Ann. Intern. Med.vol. 137, no. 10, pp. 798-804, 2002.

[83] G. Flower, H. fritz, L.G. Balneaves, S. Verma, B. Skidmore, R. Fernandes, D. Kennedy, K. Cooley, R. Wong, S. Sagar, D. Fergusson, D. Seely, "Flax and Breast Cancer: A systematic Review”, Integr. Cancer Ther. Vol. 13, no. 3, pp. 181-192, 2014.

[84] G. Lindahl, N. Saarinen, A. Abrahamsson, C. Dabrosin, "Tamoxifen, flaxseed, and the lignan enterolactone increase stroma- and cancer cell-derived IL-1Ra and decrease tumor angiogenesis in estrogen-dependent breast cancer", Cancer Res., vol. 71, no. 1, pp. 51-60, 2011.

[85] K.A. Power, N.M. Saarinen, J.M. Chen, L.U. Thompson, "Mammalian lignans enterolactone and enterodiol, alone and in combination with the isoflavone genistein, do not promote the growth of MCF-7 xenografts in ovariectomized athymic nude mice", Int J Cancer, vol. 118, no. 5, pp. 1316-1320, 2006.

[86] J. Chen, J.K. Saggar, P. Corey, L.U. Thompson LU, "Flaxseed and pure secoisolariciresinol diglucoside, but not flaxseed hull, reduce human breast tumor growth (MCF-7) in athymic mice", J Nutr. vol. 139, no. 11, pp. 2061-2066, 2009.

[87] N.M. Saarinen, K. Power, J. Chen, L.U. Thompson, "Flaxseed attenuates the tumor growth stimulating effect of soy protein in ovariectomized athymic mice with MCF-7 human breast cancer xenografts", Int J Cancer, vol. 119, no. 4, pp. 925-931, 2006.

Publish your research article in AIJR journals-

$\checkmark \quad$ Online Submission and Tracking

$\checkmark \quad$ Peer-Reviewed

$\checkmark \quad$ Rapid decision

$\checkmark \quad$ Immediate Publication after acceptance

$\checkmark \quad$ Articles freely available online

$\checkmark \quad$ Retain full copyright of your article.

Submit your article at journals.aijr.in

Publish your books with AIJR publisher-

$\checkmark \quad$ Publish with ISBN and DOI.

$\checkmark \quad$ Publish Thesis/Dissertation as Monograph.

$\checkmark \quad$ Publish Book Monograph.

$\checkmark \quad$ Publish Edited Volume/ Book.

$\checkmark \quad$ Publish Conference Proceedings

$\checkmark \quad$ Retain full copyright of your books.

Submit your manuscript at books.aijr.org 